\title{
Impact of Working Capital Management on Corporate Profitability- Empirical Evidence from Pharmaceutical Industry of Bangladesh
}

\author{
Rakibul Islam ${ }^{1}$, Mohammad Emdad Hossain ${ }^{1}$, Mohammad Nazmul Hoq ${ }^{1} \&$ Md. Morshedul Alam \\ ${ }^{1}$ Department of Business Administration, International Islamic University Chittagong, Bangladesh \\ Correspondence: Mohammad Nazmul Hoq, Assistant Professor, Department of Business Administration, \\ International Islamic University Chittagong, Bangladesh. E-mail: ronyfirst@yahoo.com
}

Received: June 6, 2018

Accepted: August 28, 2018

Online Published: August 30, 2018

doi:10.5539/ijef.v10n9p136

URL: https://doi.org/10.5539/ijef.v10n9p136

\begin{abstract}
Working capital management plays centric role in enhancing operational efficiency and their ultimate profitability. Globally financial managers have been searching the proper way on how to utilize working capital components which prolong profitability. The purpose of this study is to assess the impact of working capital components on profitability indicators of selected pharmaceutical firms in Bangladesh. The paper used financial data of 9 pharmaceutical firms listed in Dhaka stock exchange (DSE) covered 2011-2015. Two methods were used in this study for analysis data set. Firstly, to measure the relationship between selected variables Pearson Correlation matrix was used. Secondly, multiple regression analysis was used to investigate the impact working capital components on profitability of selected pharmaceutical firms. The study also conducted Durbin Watson test to assess autocorrelation of selected variables. In this study the correlation matrix identified a negative correlation between working capital components and profitability, whereas regression analysis found number of days account receivable (AR) had significant positive and current ratio (CR) and debt ratio (DR) had appeared a significant negative impact on profitability.
\end{abstract}

Keywords: working capital, profitability, inventory period, number of days account receivables, number of days account payables, cash conversion cycle, logarithm of sales, pharmaceutical firms

\section{Introduction}

Corporate finance generally focuses on the long term financial planning, valuation of future cash flow, capital budgeting, risk and return etc. Alongside, working capital is the third critical decision field of corporate financial management (Amin \& Islam, 2014). A significant portion of current asset constructs firm capital structure and converts into liquid within short period of time. Working capital has a significant impact on firm mostly in developing countries because of fundraising is harder in developing countries. This study selects nine pharmaceutical firms of Bangladesh listed in Dhaka Stock Exchange (DSE) to measure the impact of working capital components on firm's profitability.

Generally, current assets and current liabilities construct working capital. Firm can maintain its working capital efficiency to keep up higher current asset than current liabilities. The stability of any business relies on proper working capital management, causes it is directly effects on firm's profitability. It is the time of globalization and to sustain in the market any firm has to do competition with many national and international firms. However one of the most major issues meet by fund managers today is not just only procurement fund but also their significant nomination to generate maximum return. All are we know that business mostly depends on firm's performance and performance depends on overall profitability.

Maximization of profitability is the ultimate objective of any firm beside keep up liquidity is also important. Without maintaining proper liquidity firm faces insolvency and higher liquidity destructs profit. Beside if any firm cannot concern about its profit it cannot survive a longer period of time. So, we need to tradeoff between liquidity and profitability (Raheman \& Nasr, 2007). For this role authority of any firm should proper glance to deploy of working capital components. "Working capital management efficiency is vital especially for manufacturing firm where a major part of asset is current asset especially inventory and trade receivable (Arunkmar \& Ramanan, 2013)". Sometimes sales can be prolonged caused of flexible trade credit policy as well as optimal inventory. Optimal inventory reduces the risk of shortage of raw materials in the manufacturing process. Moreover, customer can examine product before purchase due to flexible trade credit which emphasize 
high sales. Many researchers used cash conversion cycle to assess working capital management. The longer cash conversion cycle implies higher investment in working capital. Management of a firm increases their sales with large cash conversion cycle. However, firm's profitability also decreases by CCC. This occur when benefits of holding is lower than the cost of financing. Overall it is a necessary and logical to carry out a study on the performance in relation to the management of working capital of the Bangladeshi pharmaceutical firms.

\section{Overview of Pharmaceutical Sector of Bangladesh}

There have several sectors on which Bangladesh can be proud and undoubtedly pharmaceutical sector is one of them. It is only capable to produce its product by use its own manufacturing capabilities. This sector contributes government exchequer which is considered second largest. Two regulatory boards control Bangladeshi pharmaceutical industry one is Director General of Drug Administration (DGDM) and another one is Pharmaceutical Council of Bangladesh (PCB). Bangladeshi pharmaceutical industry arranges of many national and international firms. The most reputed pharmaceutical companies are- Square, Beximco, Incepta, Renata, Healthcare, Kskayef etc. Bangladeshi pharmaceutical industry is dominated by local players, Square pharmaceutical leads the chair commanding an $18.8 \%$ market share which followed by Inccepta at $10.2 \%$, Beximco 8.5\%, Opsonin 5.6\% Renata 5.1\% and Eskayef 5.5\%, Radiant, Sanofi and Nova Nordisk are multinational companies enjoy $10.5 \%$ market share. Only $2 \%$ medicines are need to import and $98 \%$ covered by territorial production. Total market size of pharmaceutical industry \$2 billion (BAPI) and historical growth is $10 \%$ (2010-2014). According to (IMP), annual pharmaceutical market may be reach BDT 160 billion within 2018. Pharmaceutical industry exports their product to 100 countries. For the first time Bangladesh is going to export medicine in USA. Export of pharmaceutical product registered 14.6\% growth in (2011-2016) while the industry expected to log in receipts of $\$ 90.3$ million for the fiscal year 2016-2017 (Source: The Daily Star July 6, 2017 ). One lac fifteen thousand $(1,15,000)$ workers are working in this important sector (Sultana, 2016). Every firm needs to balance their financial elements because there is a high level of competition in market. The pharmaceutical sector faces tremendous challenge both nationally and internationally in the field of competition. One of the key elements of financial planning is working capital management. Hence pharmaceutical industry should give proper glance on managing working capital components.

\section{Literature Review}

Study conducted by Raheman and Nasr (2007) to investigate the effect of working capital management on profitability as well as liquidity on the 94 Pakistani firms listed in Karachi Stock Exchange for the period of (1999-2004). Descriptive statistics, Pearson correlation coefficient, and (pooled and general least square) regression were used. The study showed cash conversion cycle (CCC) had a significant negative relationship with profitability. The study also found a significant positive relationship between size and profitability of selected pharmaceutical firms.

Amin and Islam (2014) empirically investigated the inter-linkage of working capital and profitability. They used financial statement of fifteen listed fuel and power companies of Bangladesh listed in Dhaka Stock Exchange (DSE) of five year period from 2007 to 2011. They took two dependent variables which indicate profitability and nine independent variables. Analysis of Multiple regression and correlation matrix showed that, net profit margin (NPM) and time interest earned (TIE) have significant positive relationship and quick ratio (QR), Inventory processing period (IPP) and working capital turnover (NWC turnover) showed a significant negative relationship with ROA.

According to Arachchi et al. (2017), by reduces number of days inventories an account receivable manager can increase shareholders opulence because value of the firm depends on efficient management of working capital components. Quayyum (2012) studied on relationship of working capital components of 28 manufacturing companies listed in DSE. There were included food, pharmaceutical, engineering and cement industries. The study used regression analysis over five year period of data (2005-2009) and found a significant relationship between profitability indicators with independent variables, except the result of food industry. It concludes that firm can improve profitability by shortening its cash conversion cycle. Deloof (2003) suggested that, a firm increase its profitability by reducing the receivable collection and inventory conversion period. The study also showed there have a strong significant relationship between working capital components and profitability indicators. The result of regression analysis conducted by Lazaridis and Tyfonidis (2006) showed a statistical significant relationship between profitability with cash conversion cycle. The profitability indicator was gross operation profit. They suggested that, by managing cash conversion cycle managers could increase shareholder values. They used 131 companies as sample for the period of 2001 to 2009 which listed in Athens stock Exchange. Mohamad and Nazir (2010) collected secondary data of Bloomberg's 72 listed companies from 
(2003-2007) to assess the relationship between working capital components and profitability. The correlation and multiple regression analysis showed a significant negative relationship between working capital components with performance of these companies. They used Tobin's Q ratio and return on asset (ROA) as profitability indicators and CCC, LATA, debt to asset ratio, current ratio and current to total asset ratio as independent variables. Mousuvi \& Jari (2012) found a negative relationship between profitability and working capital by the used in data of 56 companies accepted Tehran stock exchange. Kasozi (2017) used data of 69 manufacturing firms listed in Johannesburg Securities Exchange (JSE) during the period of 2007-20016. He found average collection period are negative and inventory conversion period have a positive statistically significant relationship with profitability. Additionally the study argued that large inventory reduces the possibility of stock out. Wasiuzzaman (2015) analyzed the relationship between working capital and its components with profitability by used 160 manufacturing firms of Malaysia. He used ordinary least squares regression technique and found a negative relationship between the components of working capital with profitability except payable period and in this study he argued that, economic policy may have impact on the relationship of working capital and profitability. Zakaria and Saidu (2010) found that efficiency of cash conversion cycle depends on how a firm collected their receivable and payment of their bills and cash conversion cycle showed a positive relationship in their empirical study where they used data of listed telecommunication firm from Nigerian stock exchange from 2010-2014.

\section{Data and Methodology}

The study used secondary data which was collected from annual audited report of listed pharmaceutical firms listed in DSE. All listed pharmaceutical firms did not have fully five years financial report, due to this fact the study has been completed by nine among thirteen firms listed in DSE. The recent data of fiscal year 2016-2017 couldn't arrange for the study because of changing the ending time of their financial statement. As per new government regulation, companies other than Bank, Insurance and Non-Banking financial institution are required to maintain July-June their financial year. For that, these companies represented their financial statement as prescribed by the government. Finally, the study collected financial data of nine listed pharmaceutical firms during 2011-2015.

The study tries to undertake fundamental variables that dominance working capital management of Bangladeshi firms. The study selected dependent, independent and control variables. The following table depicts selected variables and their measuring methods.

Table 1. Variables chosen for the study

\begin{tabular}{|c|c|c|}
\hline Variables & Definition & Operationalization \\
\hline \multicolumn{3}{|c|}{ Dependent Variable } \\
\hline \multirow[t]{2}{*}{ ROA } & Return on Asset & (EBIT)Earnings Before Taxes \\
\hline & & Total Asset \\
\hline \multicolumn{3}{|c|}{ Independent Variables } \\
\hline \multirow[t]{2}{*}{ IV } & Number of Days Inventory & Inventories \\
\hline & & Cost of Goods Sold/365 \\
\hline \multirow[t]{2}{*}{ AR } & Number of Days Account & Receivable \\
\hline & Receivable & Net Sales/365 \\
\hline \multirow{2}{*}{$\mathrm{AP}$} & \multirow{2}{*}{ Number of Days Account Payable } & Trade Payable \\
\hline & & Cost of Goods Sold/365 \\
\hline $\mathrm{CCC}$ & Cash Conversion Cycle & $\begin{array}{c}\text { Number of Days Inventory+Number of Days Account Receivable - } \\
\text { Number of Days Account Payable }\end{array}$ \\
\hline $\mathrm{CR}$ & Current Ratio & Current Asset/ Current Liabilities \\
\hline \multicolumn{3}{|c|}{ Control Variables } \\
\hline $\mathrm{LN}$ & Firm Size & Logarithm of Sales \\
\hline DR & Debt Ratio & Total Liabilities/ Total Asset \\
\hline
\end{tabular}

The study used statistical Package for Social Science (SPSS, version 20) for analysis. The study conducted Durbin Watson test to assess autocorrelation of selected variables. Four is the upper limit and zero is the lower limit of Durbin Watson values. To described and discussed features of data fairly the study used descriptive statistics. Two methods were used to analysis of these data. Firstly, to measure the relationship between selected 
variables Pearson Correlation matrix was used. Secondly, Multiple Regression was used to investigate the impact working capital components on profitability of selected pharmaceutical firms. For regression analysis the study selected a model to explore the impact of working capital management on profitability. The model was exposed generally as:

$$
\begin{aligned}
\mathrm{ROA} & =f(\mathrm{IV}, \mathrm{AR}, \mathrm{AP}, \mathrm{CCC}, \mathrm{LN}, \mathrm{CR}, \mathrm{DR}) \\
& >\text { Model 1: } \mathrm{ROA}_{\mathrm{it}}=\beta_{0}+\beta_{1}\left(\mathrm{IV}_{\mathrm{it}}\right)+\beta_{2}\left(\mathrm{LN}_{\mathrm{it}}\right)+\beta_{3}\left(\mathrm{CR}_{\mathrm{it}}\right)+\beta 4\left(\mathrm{DR}_{\mathrm{it}}\right)+\epsilon_{\mathrm{it}} \\
& >\text { Model 2: } \mathrm{ROA}_{\mathrm{it}}=\beta_{0}+\beta_{1}\left(\mathrm{AR}_{\mathrm{it}}\right)+\beta_{2}\left(\mathrm{LN}_{\mathrm{it}}\right)+\beta_{3}\left(\mathrm{CR}_{\mathrm{it}}\right)+\beta 4\left(\mathrm{DR}_{\mathrm{it}}\right)+\epsilon_{\mathrm{it}} \\
> & \text { Model 3: } \mathrm{ROA}_{\mathrm{it}}=\beta_{0}+\beta_{1}\left(\mathrm{AP}_{\mathrm{it}}\right)+\beta_{2}\left(\mathrm{LN}_{\mathrm{it}}\right)+\beta_{3}\left(\mathrm{CR}_{\mathrm{it}}\right)+\beta 4\left(\mathrm{DR}_{\mathrm{it}}\right)+\epsilon_{\mathrm{it}} \\
> & \text { Model 4: } \mathrm{ROA}_{\mathrm{it}}=\beta_{0}+\beta_{1}\left(\mathrm{CCC}_{\mathrm{it}}\right)+\beta_{2}\left(\mathrm{LN}_{\mathrm{it}}\right)+\beta_{3}\left(\mathrm{CR}_{\mathrm{it}}\right)+\beta 4\left(\mathrm{DR}_{\mathrm{it}}\right)+\epsilon_{\mathrm{it}}
\end{aligned}
$$

\section{Analysis and Findings}

This chapter expects to provide empirical interpretation of selected variables based on some test which have been conducted in this study. However this chapter organized by descriptive statistics, correlation matrix and regression analysis.

\subsection{Descriptive Statistics}

To describe the basic features of variables this study uses descriptive statistics which represents average, minimum, maximum, standard deviation, skewness and kurtosis of the selected variables. This study shows there is really enormous difference between number of days inventory, number of days account receivable, cash conversion cycle also profitability (ROA) by their minimum and maximum values expressed in the table.

Table 2. Descriptive statistics

\begin{tabular}{llllllll}
\hline VAR. & N & MIN & MAX & Mean & ST.DV & Skewness & Kurtosis \\
\hline ROA & 9 & 0.016 & 0.202 & 0.092 & 0.065 & 0.557 & -0.935 \\
IV & 9 & 33.1 & 635.153 & 262.331 & 211.654 & 0.767 & -0.427 \\
AR & 9 & 0.568 & 153.867 & 56.909 & 46.579 & 1.162 & 1.415 \\
AP & 9 & 7.89 & 68.179 & 22.811 & 18.469 & 2.256 & 5.394 \\
CCC & 9 & 15.859 & 665.423 & 296.429 & 217.616 & 0.546 & -0.665 \\
LN & 9 & 8.056 & 10.266 & 9.131 & 0.839 & 0.039 & -1.767 \\
CR & 9 & 0.827 & 2.182 & 1.376 & 0.521 & 0.539 & -1.438 \\
DR & 9 & 0.197 & 0.841 & 0.469 & 0.205 & 0.714 & 0.046 \\
\hline
\end{tabular}

One pharmaceutical company earned $1.6 \%$ return on their assets within the time period (2011-2015) where other earned $20.2 \%$. On average the firms were gained $9.2 \%$ on return their assets. The standard deviation is $6.5 \%$. This mean that the firms value if return can deflect from the mean value to both sides by $6.5 \%$. The coefficient of skewness 0.577 implies the data is positively skewed and does not meet the symmetrical distribution requirements. Similarly, the value of kurtosis is -0.935 suggests that such data does not meet the normal distribution assumption.

However, a company takes 33.100 days to conversion their raw materials and sales their products where the other one takes 635.153 days to performed same task. The rational may have technological difference, difference in their products nature and also may have different strategy of their supply chain management. On average selected firms took 262.331 days for their inventory period and standard deviation is 211.654 days.

Concerning number of days account payable 7.890 is minimum and 68.179 is the maximum periods for paying for their supplier. The average paying period is 22.811 days and standard deviation is 18.469 . Similarly, the coefficient of kurtosis is 5.394 implies that the normal distribution assumption does not meet.

For receivable period, the minimum and maximum values are 0.568 and 153.867 days respectively and standard deviation is 51.12 days. The coefficient of skewness 1.162 that means the data does not meet symmetrical distribution assumption. On the other hand, the kurtosis vale is 1.415 also shows that is the data does not meet the normal distribution assumption.

The minimum and maximum values of cash conversion cycle show huge difference. When one firm use 665.423 days to conversion their cash where other takes only 15.859 days. The mean value of CCC is 296.429 days. This implies, on average the selected firms takes 296.429 days for completing one cycle. The coefficient of skewness 0.546 implies that the data is positively skewed and thus does not comply with the symmetrical distribution 
requirements. Moreover, the coefficient of kurtosis is -0.665 indicates that the $\mathrm{CCC}$ variables do not meet normal distribution requirements.

Generally current ratio (CR) traditionally used to measure the liquidity position of any firm. The study also used current ration to measure selected firms liquidity position. The average value of CR is 1.376 with a standard deviation of 0.521 . The lowest and higher CR is 0.827 and 2.182. The coefficient of skewness 0.539 implies that the data is positively skewed, and therefore does not meet symmetrical distribution requirements. Moreover the coefficient of kurtosis -1.438 indicates the $\mathrm{CR}$ variable does not meet the normal distribution criteria.

Pertaining the study used natural logarithm of sales, and debt ratio as control variable. The size of firm and its relationship with profitability is measured by the natural logarithm of sales. The range of log of sales is from 8.056 to 10.266 with their minimum and maximum values. The mean value of log of sales is 9.131 and standard deviation is 0.839 . The coefficient of skewness 0.039 implies that the data is positively skewed and the coefficient of kurtosis -1.767 which means $\mathrm{LN}$ variable does not meet normal distribution assumption.

The maximum debt financing used by a company is $84.1 \%$ it means the company uses more debt than equity financing and the minimum debt uses rate is $19.7 \%$. The average debt ratio of pharmaceutical firms is $46.9 \%$ and standard deviation is $20.5 \%$. The coefficient of skewness .741 implies the data is positively skewed, that the data does not meet symmetrical distribution requirements. The kurtosis value is .046 also suggest that majority of the values are higher than mean and do not meet normal distribution assumption.

\subsection{Correlation Analysis}

The interrelationship between selected variables has been analyzed using correlation coefficient. The corre0lation matrix contains the simple Pearson correlation coefficient.

Table 3. Pearson correlation coefficients

\begin{tabular}{|c|c|c|c|c|c|c|c|c|c|}
\hline VAR. & & ROA & IV & $\mathbf{A R}$ & AP & $\mathrm{CCC}$ & $\mathbf{L N}$ & $\mathbf{C R}$ & DR \\
\hline ROA & Pearson Correlation & 1 & & & & & & & \\
\hline IV & Pearson Correlation & -.242 & 1 & & & & & & \\
\hline $\mathbf{A R}$ & Pearson Correlation & -.120 & -.072 & 1 & & & & & \\
\hline $\mathbf{A P}$ & Pearson Correlation & -.193 & -.232 & -.128 & 1 & & & & \\
\hline $\mathrm{CCC}$ & Pearson Correlation & -.243 & $.963^{* * *}$ & .185 & -.349 & 1 & & & \\
\hline $\mathbf{L N}$ & Pearson Correlation & $.586^{*}$ & .056 & $-.670^{* *}$ & -.388 & -.071 & 1 & & \\
\hline CR & Pearson Correlation & -.223 & .162 & .309 & -.461 & .274 & -.136 & 1 & \\
\hline DR & Pearson Correlation & $-.586^{*}$ & .146 & .083 & .363 & .125 & $-.648 *$ & $-.582 *$ & 1 \\
\hline
\end{tabular}

***. Correlation is significant at the 0.01 level (2-tailed); **. Correlation is significant at the 0.05 level (2-tailed); *. Correlation is significant at the 0.10 level (2-tailed).

The presented table (3) enumerates that LN has a positive relationship with profitability and their relationship is statistically significant with coefficient 0.586 which implies the bigger the firm size the higher the profitability and vice versa and the relationship complies the relationship conducted by Raheman and Nasr (2007) and Wasizzaman, (2015). Correlation result of LN and AR also shows a significant negative relationship between them with coefficient -0.670 . This means large firm collects their receivable rapidly compares to small firm. Rahamn and Nasr (2007) also find out same result.

Raheman and Nasr (2007); Kasozi (2017); Iqbal, Ahmad, and Riaz (2014); Usman, Sheikh, and Khan (2017); Tuffaur and Bouteng (2017), found out a positive relationship between CCC and IV in their empirical study. In the same way this study finds alike result between them and their relationship is highly significant with coefficient 0.936 . This means higher inventory period prolongs CCC which influence on firm's profitability.

However the correlation result shows a negative significant relationship between leverage and firm's profitability with coefficient -0.586 . This implies high leveraged firm earns less than low leveraged firm. Kasozi (2017); Asduzzaman and Chowdhury (2017); Usman, Shakil, and Khan (2014) also found out same result in their study.

Moreover debt ratio shows a significant negative relationship with logarithm of sales and current ratio with their coefficient -0.648 and -0.582 . This means large firm maintains lower debt than small firms and low leveraged firms maintain high liquidity compare to high leveraged firms and these relationships also same as the study of Usman, Shaikh, and Khan, (2017); Baser et al. (2016) and Vintila and Nenu (2016).

\subsection{Regression Analysis}

For assessing the nature and degree of dependent criterion variable (ROA) on selected working capital efficiency 
indicators multiple regression analysis are performed. The summary of multiple regression analysis are show by respective table.

Table 4. Model (1, 2, 3 \& 4) summary

\begin{tabular}{|c|c|c|c|c|c|c|c|c|}
\hline \multirow[t]{2}{*}{ Model } & \multirow[t]{2}{*}{$\mathrm{R}$} & \multirow[t]{2}{*}{ R Square } & \multirow{2}{*}{$\begin{array}{l}\text { Adjusted } \\
\text { R Square }\end{array}$} & \multirow{2}{*}{$\begin{array}{l}\text { Std. Error of } \\
\text { the Estimate }\end{array}$} & \multicolumn{3}{|c|}{ Change Statistics } & \multirow[t]{2}{*}{ Durbin-Watson } \\
\hline & & & & & R Square Change & F Change & Sig. F Change & \\
\hline 1 & .911 & .830 & .660 & .03702983 & .830 & $4.880 *$ & .077 & 1.966 \\
\hline 2 & .999 & .997 & .994 & .00483596 & .997 & $343.735^{* * *}$ & .000 & 2.345 \\
\hline 3 & .940 & .883 & .766 & .03070787 & .883 & $7.550 * *$ & .038 & 1.883 \\
\hline 4 & .920 & .847 & .694 & .03511536 & .847 & $5.538 *$ & .063 & 2.279 \\
\hline
\end{tabular}

***. Regression is significant at the 0.01 level; **. Regression is significant at the 0.05 level; *. Regression is significant at the 0.10 level.

The adjusted $\mathrm{R}^{2}$ of first model is $66 \%$ which indicates that the selected predictors of this model explain uniquely or jointly $66 \%$ variation in ROA and the formula is strong fit. It also shows that relationships of those variables are statistically significant at $10 \%$ level of significance. The second regression is run by using receivable period instead of inventory period as an independent variable. The other variables are same like first regression. The adjusted $\mathrm{R}^{2}$ of second model is $99.4 \%$ which indicates that the selected predictors of this model explain uniquely or jointly $99.4 \%$ variation in ROA and the formula is strongly fit. It also shows that influences of those variables are highly significant at $1 \%$ level of significance. Third regression is run by using the payment period as an independent variable as a substitute receivable period. The other variables are same like our first and second regression. The adjusted $\mathrm{R}^{2}$ of the model is $76.6 \%$ which indicates that the selected predictors of this model explain uniquely or jointly $76.6 \%$ variation in ROA and the formula is strongly fit. It also shows that influences of those variables are highly significant at 5\% level of significance. In fourth and last regression of this study, cash conversion cycle applied as independent variable instead of other variables used in first, second and third regression model. The other variables are kept the same as they are in the first three regressions. The adjusted $\mathrm{R}^{2}$ of above model is $69.4 \%$ which indicates that the selected predictors of this model explain uniquely or jointly $69.4 \%$ variation in ROA and the formula is strong fit. It also shows that influences of those variables are significant at $10 \%$ level of significance. The unexplained parts of all models are standard error. The collinearity of all model are below the required level which are 1.966, 2.345, 1.883 and 2.279, which indicates there is no multicollinearity among the independent variables.

Table 5. Model (1, 2, 3 \& 4) coefficients

\begin{tabular}{|c|c|c|c|c|c|}
\hline \multirow[t]{2}{*}{ Model } & \multirow[t]{2}{*}{ Variables } & \multicolumn{2}{|c|}{ Unstandardized Coefficients } & \multirow{2}{*}{$\begin{array}{c}\text { Standardized Coefficients } \\
\text { Beta } \\
\end{array}$} & \multirow[t]{2}{*}{$\mathrm{T}$} \\
\hline & & $\mathrm{B}$ & Std. Error & & \\
\hline \multirow{5}{*}{1} & (Constant) & .426 & .288 & & 1.475 \\
\hline & IV & .000024 & .000 & .070 & .297 \\
\hline & $\mathrm{LN}$ & -.003 & .024 & -.033 & -.106 \\
\hline & $\mathrm{CR}$ & -.109 & .037 & -.893 & $-2.933 * *$ \\
\hline & DR & -.352 & .124 & -1.138 & $-2.825 * *$ \\
\hline \multirow{5}{*}{2} & (Constant) & -.189 & .052 & & $-3.667 * *$ \\
\hline & $\mathrm{AR}$ & .001 & .000 & .731 & $15.353 * * *$ \\
\hline & $\mathrm{LN}$ & .055 & .005 & .723 & $11.909 * * *$ \\
\hline & $\mathrm{CR}$ & -.120 & .005 & -.986 & $-26.665 * * *$ \\
\hline & DR & -.232 & .016 & -.752 & $-14.604 * * *$ \\
\hline \multirow{5}{*}{3} & (Constant) & .558 & .251 & & $2.220^{*}$ \\
\hline & $\mathrm{AP}$ & -.001 & .001 & -.295 & -1.395 \\
\hline & $\mathrm{LN}$ & -.011 & .020 & -.146 & -.548 \\
\hline & $\mathrm{CR}$ & -.124 & .031 & -1.019 & $-3.963 * *$ \\
\hline & DR & -.361 & .094 & -1.167 & $-3.850 * *$ \\
\hline \multirow{5}{*}{4} & (Constant) & .443 & .262 & & 1.688 \\
\hline & $\mathrm{CCC}$ & .000055 & .000 & .165 & .739 \\
\hline & $\mathrm{LN}$ & -.003 & .022 & -.045 & -.157 \\
\hline & $\mathrm{CR}$ & -.117 & .036 & -.957 & $-3.233^{* *}$ \\
\hline & DR & -.369 & .115 & -1.193 & $-3.217 * *$ \\
\hline
\end{tabular}

***. Regression is significant at the 0.01 level; **. Regression is significant at the 0.05 level; *. Regression is significant at the 0.10 level. 
The above table depicts the coefficient of regression equation and the independent effect of predictors upon dependent variable. In first model there is only two variables current ratio (CR) and debt ratio (DR) is statistically significant at 5\% level of significance. The result presented in the table shows that inventory period has positive relationship with profitability (ROA). The coefficient is 0.000024 and the relationship is not statistically significant. There was some studies provided same result (Olufisayo, 2011; Nobanee, 2009; David, 2010). This means high inventory period positively affects profitability because high inventory levels reduce cost of possible interruption in the production process and loss of business due to shortage of raw inventories.

In this study natural logarithm (LN) measure the size of the firm based on sales. The LN displays opposed relationship with profitability which is not statistically significant. That indicates size of firms adversely influence on its profitability, the smaller the size firms have more profitable compare to firms of bigger size.

Moreover, the current ratio, which measures the solvency of any business entity, shows a significant negative relationship with profitability. The finding supports the finding of Rahman and Nasr (2007); Amin and Islam (2014); Olufisayo (2012); Padachi (2006). The negative impact implies if a firm holds more current assets it adversely effects on its profitability.

Similarly, The debt ratio used in this study as a proxy for leverage; which indicates significant negative relationship with profitability (ROA). The finding is consistent the findings of Kasozi (2017); Rahman and Nasr (2007); Padachi (2006); Olufisayo (2012).The negative relationship of leverage may give a hint, if the firm used more leverage in its capital structure which trend high liquidity position. However high liquidity is negatively affected the profitability of this firm.

The result of regression two presents above table shows singly all variables are highly significant at $1 \%$ level of significance. The coefficient of receivable period is positive and highly significant with its coefficient 0.001 . The findings support the finding of Nobanee (2009); Olufisayo (2012). The positive relationship indicates receivable period have a significant effect on profitability by its minimization and maximization. "Emery (1984), identifies trade credit as a more profitable short term investment than marketable securities". "Deloof and Jegers (1996) mentioned higher profits should lead to more accounts receivable, because firms with higher profits have more cash to lend to customers".

The result show retro impact in case of natural logarithm of sales (LN) compare to the first model. It shows a positive significant relationship with ROA. The finding is consistent with the findings of Rahman and Nasr (2007); Olufisayo (2012); Deloof (2003). This impact indicates the bigger size firms more profitable compare to the smaller size firm. The current and debt ratio shows a significant negative relationship with profitability.

However, in third model we see that, only current and debt ratio is significant at $5 \%$ level of significance. The result shows the relationship between number of days account payables and ROA is negative and the relationship is not significant. This finding is consistent the finding of Hayajneh and Yassine (2011); Nobanee (2009). The opposite relationship of payment period indicates more profitable firm pay their bill (supplier) as soon as they can. The size of the firm, liquidity ratio and leverage shows a negative relationship with profitability (ROA) like the first regression. But the relationship of firm size with profitability is not significant.

Moreover, in fourth model current and debt ratio is statistically significant like our first and third regression. The outcome of the model four indicates cash conversion cycle has positive impact on profitability and the relationship is not significant. The findings supports the findings of Grill, Biger and Mathur (2010); Nobanee (2009). The rationale is that, may optimum level of inventory prolonging sales and the cost of capital may lower than the cost of holding more inventories and create more credit to customer. The other variables show a negative relationship with profitability (ROA) like the first and third regression. But the relationship of firm size with profitability is not significant.

\section{Summary and Conclusion}

Working capital is very important for manufacturing firms particularly in developing countries because fundraising is harder in developing countries and majority of firms are small in developing countries like Bangladesh. Firms in developing countries lack the opportunity to getting the benefit of financial market. If the market exist the small firms have less opportunity to go public even bank hesitate to provide long term loans. Moreover most of Bangladeshi people have not sufficient knowledge about financial market. Working capital considered as lifeblood of firms and it helps to perform daily operation, to fulfill capital structure, and investment in other activities which firms manage their working capital efficiently considered healthy firms. Therefore efficient manage of working capital helps firm to lower borrowing and reinvest its surplus capital to grown shareholder value. According to this study endeavors to provide empirical evidence based on the impact 
of working capital management of selected pharmaceutical firms listed in DSE during 2011-2015. The study tries to find out the probable impact of working capital components on profitability.

Based on the key findings the study, Considering the coefficients and their significance level, it can be concluded that in Pharmaceutical Industry, Number of days inventories (IV), Number of days account receivables (AR), Number of days account payable (AP), Cash Conversion Cycle in Days (CCC), Liquidity management (CR), Size of firms (LN) and leverage of firms (DR) plays an important role in determining Pharmaceutical Industries' overall profitability Return on Assets (ROA). In particular, this study finds that Inventory period (IV) Statistically insignificant positive impact on profitability (ROA) of listed pharmaceutical firms in Bangladesh. The study also finds receivable period has highly significant positive impact on profitability. Moreover, the result provides that Payable period (AP) has a negative impact on profitability but the impact is insignificant. In addition cash conversion cycle has insignificant positive impact on profitability of listed pharmaceutical firms of Bangladesh.

It also finds that liquidity (CR) and debt ratio (DR) has significant negative impact on profitability. But at the time of considering size of a firm, logarithm of sales (LN) to investigate its impact on profitability showed both negative and positive significant and insignificant result. Leave aside regression model 2 the LN shows a negative insignificant result. In regression model-2 (LN) showed that, (LN) has a statistically positive impact on profitability of listed Bangladeshi pharmaceutical firms. This is the evidence from the study that working capital plays an important role in the overall performance of the industry.

From the output of the analysis, this study recommends some probable action that can be take manger of pharmaceutical firms-

$\checkmark$ Pharmaceutical firms mostly depends on imports for procurement their raw materials, so their lead time is high and many firms exports their products to many countries, so delivery time is an important matter. To consider these things financial firms should maintain an optimal level of inventory to avoid scarcity of raw materials and finish good.

$\checkmark \quad$ Pharmaceutical firms should keep optimum level of accounts receivable and cash conversion cycle to enlarge profitability. This could only be possible when pharmaceutical firms give due regard to every components of cash conversion cycle.

$\checkmark \quad$ Management of pharmaceutical firms should involve in credit terms bargaining with their supplier in order to optimizing their payable efficiency.

$\checkmark \quad$ Pharmaceutical firms should minimize their leverage position which directly or indirectly will diminish their liquidity position. Thereby, it enhances their profitability.

The findings of this study are not free from limitations. The finding of this study could only be generalized to listed pharmaceutical firms cover in this study. Moreover, the time frames and unavailability of recent data finite the latitude of this study.

The analysis of this study is done with annual data. Future researcher can take quarterly data to get more accurate results.

\section{References}

Amin, S., \& Islam, M. A. (2014). Impact of working capital management on firm's profitability: Evidence from the fuel and power companies listed on the Dhaka stock exchange. Journal of Business Studies, xxxv(1), 177-199.

Arachchi, A. N. H., Perera, W., \& Vijaykumaran, R. (2017). The impact of working capital management on firm value: Evidence from frontier market. Asian Journal of Finance \& Accounting, 9(2). https://doi.org/10.5296/ajfa.v9i2.12449

Arunkumar, O. N., \& Ramanan, T. R. (2013). Working Capital Management and profitability: A Sensitivity Analysis. International Journal of Research and Development: A Management Review, 2(1), 52-58.

Assaduzzaman, M., \& Chowdhury, T. (2014). Effect of working capital management on firm profitability: Empirical evidence from textile industry of Bangladesh. Research Journal of Finance and Accounting, 5(8).

Baser, F., Gokten, S., kucukkocaoglu, G., \& Ture, H. (2016). Liquidity and profitability tradeoff existence in Turkey: An empirical investigation under structural equation modeling. Copernican Journal of Finance and Accounting, 5(2), 27-44. https://doi.org/10.12775/CJFA.2016.013

David M. M. (2010). The influence of working capital management components on corporate profitability: A 
survey on Kenyan Listed firms. Research Journal of Business Management, 4(1), 1-11. https://doi.org/10.3923/rjbm.2010.1.11

Deloof, M. (2003). Does working capital management affects profitability of Belgian firms? Journal of Business, Finance and Accounting, 30(3-4), 573-588. https://doi.org/10.1111/1468-5957.00008

Deloof, M., \& Jegers, M. (1996). Trade credit product quality and Intra group Trade: Some European Evidence. Finance Management, 25, 33-43. https://doi.org/10.2307/3665806

Dong, H. P., \& Su, J. (2010). The Relationship between Working Capital Management and Profitability: A Vietnam Case. Int. Research Journal of Finance and Economics, 49, 59-67.

Emerym G. W. (1987). An optimal financial response to variable demand. Journal of Financial and Quantitative Analysis, 22, 209-225. https://doi.org/10.2307/2330713

Grill, A., Biger, N., \& Mathur, N. (2010). The relationship between working capital management and profitability: Evidence from the United States. Business and Economic Journal, BEJ-10. Retrieved from http://astonjournals.com/bej

Hayajneh, O. S., \& Yassine, F. L. (2011). The impact of working capital efficiency on profitability- An empirical analysis on Jordanian manufacturing firms. International Research Journal of Finance and Economics, 67-76.

Hiller, D., Ross, S., \& Yassine, F. L. (2011). The impact of working capital efficiency on profitability- An empirical analysis on Jordanian manufacturing firms, International Research Journal of Finance and Economics, 67-76.

Iqbal, N., Ahmad, N., \& Riaz, Z. (2014). The relationship between working capital management and profitability: evidence from Pakistan. International Letters of Social and Humanistic Sciences, 20, 14-25. https://doi.org/10.18052/www.scipress.com/ILSHS.20.14

Kasozi, J. (2017). The effect of working capital management on profitability: A case of listed manufacturing firms in South Africa. Investment Management and Financial Innovations, 14(2-2), 336-346. https://doi.org/10.21511/imfi.14(1-1).2017.11

Lazaridis, I., \& Tryfonidis, D. (2006). Relationship between working capital management and profitability of listed companies in the Athens stock exchange. Journal of Financial Management and Analysis, 19(1), 26-35.

Long, M. S., Maltiz, I. B., \& Ravid, S. A. (1993). Trade credit, Quality guarantees and product marketability. Financial Management, 22(4), 117-127. https://doi.org/10.2307/3665582

Mousuvi, Z., \& Jari, A. (2012). The Relationship between Working Capital Management and Firm Performance: Evidence from Iran. International Journal of Humanities and Social Science, 2(2).

The Daily Star. July 6, 2017.

Tuffour, J. K., \& Boateng, J. A. (2017). Is working capital management important? Empirical evidence from manufacturing companies in China. Review of Innovation and Competitiveness, 3(1).

Usman, M., Shaikh, S. A., \& Khan, S. (2017). Impact of working capital management on firm profitability: Evidence from Scandinavian countries. Journal of Business Studies, 11(1), 99-112. https://doi.org/10.29270/JBS.11.1(17).006

Vintila, G., \& Nenu, E. A. (2016). Liquidity and profitability analysis on the Romanian listed company. Journal of Eastern Europe Research in Business and Economics, 8. https://doi.org/10.5171/2016.161707

Wasiuzzaman, S. (2015). Working capital and profitability in manufacturing firms in Malaysia: An empirical study. Global Business Review, 16(4), 545-566. https://doi.org/10.1177/0972150915581098

Zakaria, M., \& Saidu, S. (2010). The impact of cash conversion cycle on firms' profitability: Evidence from Nigerian listed telecommunication companies. Journal of Finance and Accounting, 4(6), 342-350. https://doi.org/10.11648/j.jfa.20160406.15

\section{Copyrights}

Copyright for this article is retained by the author(s), with first publication rights granted to the journal.

This is an open-access article distributed under the terms and conditions of the Creative Commons Attribution license (http://creativecommons.org/licenses/by/4.0/). 